\title{
Impact of Meteorological Parameters on the COVID-19 Incidence: The Case of the City of Oran, Algeria
}

\author{
Farid Rahal ${ }^{1^{*}}$, Salima Rezak ${ }^{2}$, Fatima Zohra Baba Hamed ${ }^{3}$
}

\begin{abstract}
${ }^{1}$ Laboratory of Science, Technology and Process Engineering, University of Science and Technology of Oran Mohamed BOUDIAF, Oran, Algeria

${ }^{2}$ Laboratory of Inorganic Materials Chemistry and Applications, University of Science and Technology of Oran - Mohamed BOUDIAF, Oran, Algeria

${ }^{3}$ Civil Engineering Department, University of Science and Technology of Oran - Mohamed BOUDIAF, Oran, Algeria
\end{abstract}

\begin{abstract}
The current coronavirus disease 2019 (COVID-19) pandemic in the major countries of the world has become a serious threat to the health of all human beings. A better understanding of the effective parameters in infection spreading can bring about a logical measurement toward COVID-19. Among these parameters, we find the climatic factors that can play an important role in the spread of the COVID-19 epidemic. We have studied this phenomenon in the city of Oran in Algeria, which experienced its first case of COVID-19 on March 19, 2020.

In this study, the main parameters, including the number of infected people with COVID-19, the average, minimum and maximum temperatures, the relative humidity rate and the wind intensity.

A first analysis of the data with a Spearman rank correlation test did not yield significant results. Taking into account the average incubation period to adjust the data made it possible, during a second analysis, to show that the minimum temperature is significantly correlated with the new cases of COVID-19 in Oran city, but further studies over longer periods with additional parameters are needed to better understand this matter.
\end{abstract}

Keywords: COVID-19, temperature, humidity, wind, incubation period

\section{Correspondence:}

Farid Rahal

Address: Laboratory of Science, Technology and Process Engineering, University of Science and Technology of Oran - Mohamed BOUDIAF, Oran, Algeria

Email: farid.rahal.dz@gmail.com
Received: 29.07.2020,

Accepted: 15.10.2020

https://doi.org/10.29333/jcei/9562

\section{INTRODUCTION}

Millions of people have been put on lockdown in order to reduce the transmission of the COVID-19. This epidemic has also changed the people's life style; caused extensive job losses and threatened the sustenance of millions of people, as businesses have shut down to control the spread of virus [1].

The transmission of viruses can be impacted by several factors, including climatic conditions such as temperature, humidity and wind as well as population density [2]. Many research works have been carried out on this field $[3,4,5,6]$ since the World Health Organization (WHO) declared that the COVID-19 pandemic is a Public Health Emergency of International Concern (PHEIC), on January 30, 2020.

Algeria, like other countries in the world, has not escaped this COVID-19 pandemic. The first case reported on February 25, 2020, was imported from Italy [7]. In order to limit exposure to the virus, partial containment measures were imposed on some cities that reported the highest number of contaminated cases. More and more people are invited to isolate themselves or to quarantine themselves, they only leave their homes to buy essential items such as food and medicines [8].

The city of Oran in Algeria is a significant example of the COVID-19 epidemic evolution in Algerian urban areas. The main objective of this work is to find the meteorological parameters that contribute to the spread of COVID-19 in Oran city.

\section{THEORETICAL FRAMEWORK}

The behavior of an enveloped virus is affected by extra-human conditions, such as climatic conditions [9]. Hence, the effect of climatic factors on spreading of COVID-19 can play an important role in the new Coronavirus outbreak [10].

It has been reported that there is a negative relationship between COVID-19 mortality and temperature [11] because at lower temperatures, the performance of the. 


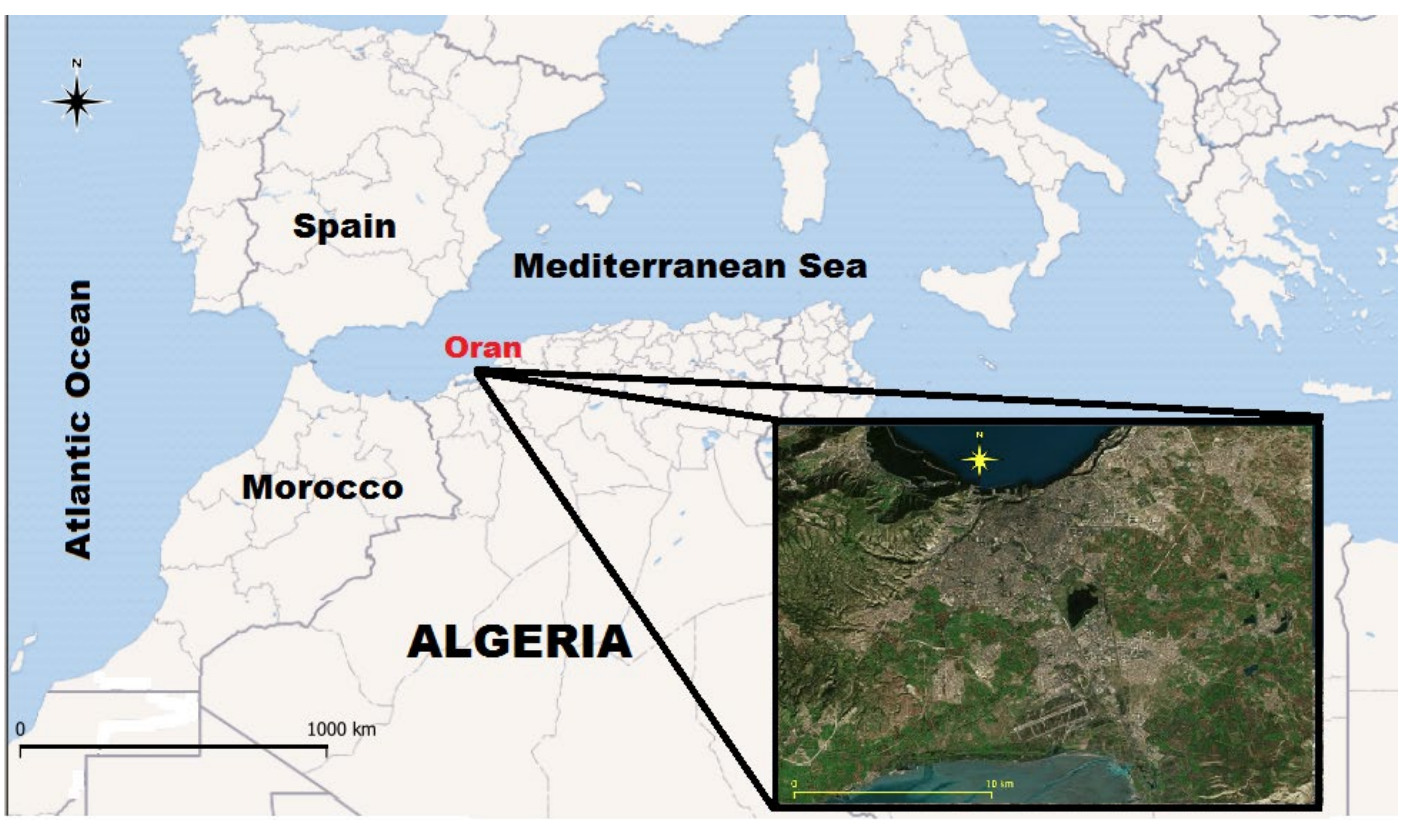

Figure 1. Geographical position of the city of Oran.

Source: Authors

immune system, as well as the liver, is decreased; as a result, the situation will be conducive to the activity of infectious agents and virus transmission [12-16].

Both epidemiological and laboratory studies have shown that ambient temperature could affect the transmission and survival of coronaviruses. Xie et al. [17] found that mean temperature has a positive linear relationship with the number of COVID-19 cases with a threshold of $3{ }^{\circ} \mathrm{C}$.

Temperature increase and sunlight can facilitate the destruction of SARS-COV-2 and the stability of it on surfaces. Eslami et al. [18] show that when the minimum ambient air temperature increases by $1{ }^{\circ} \mathrm{C}$, the cumulative number of cases decreases by $0.86 \%$.

Indeed, high temperatures damage the virus lipid layer decreasing its stability and infection potential and may even cause virus inactivation, therefore lowering the transmission rate $[19,20]$.

\section{MATERIALS AND METHODS}

\section{Sample and Sources}

The Oran region is characterized by a semi-arid climate [21] with annual rainfall less than $330 \mathrm{~mm}$, occurring mainly between the months of October and May; average monthly temperatures vary between $5^{\circ}$ and $17^{\circ} \mathrm{C}$ in winter and $16^{\circ}$ and $31^{\circ} \mathrm{C}$ in summer [22].

The city of Oran is located in the northwest of Algeria, bordered by the Mediterranean Sea to the north and the Sebkha to the southwest as shown in Figure 1.

Bukhari et al. [23] have shown that low temperature and humidity levels are key variables in determining the transmission of COVID-19. Therefore, it is interesting to study this phenomenon for the region of Oran.
For this study, we used the meteorological data recorded, during the months of April, May and June, at the meteorological station of Es Senia concerning minimum temperature $\left({ }^{\circ} \mathrm{C}\right)$, average temperature $\left({ }^{\circ} \mathrm{C}\right)$, maximum temperature $\left({ }^{\circ} \mathrm{C}\right)$, relative humidity $(\%)$ and wind intensity $(\mathrm{km} / \mathrm{h})$. Data on new COVID-19 cases in Oran are from the MSPRH [7].

\section{Measures}

The meteorological parameters were obtained from the Algerian Meteorological Office. The temperature was measured in ${ }^{\circ} \mathrm{C}$ from March to June, 2020 and the humidity in $\%$ for the same period.

The wind is implied as a critical climatic factor for the transmission of COVID-19 [24]. Hence, we also collected wind data in $\mathrm{km} / \mathrm{h}$ regarding the study period from March to June, 2020.

COVID-19 infection data is considerate as number of cases COVID-19 per 10,000 inhabitants and collected from MSPRH [7].

\section{Data Analysis Procedure}

Before using a statistical analysis, it is necessary to verify that the sample follows a normal distribution or not. Given the size of our data, the Shapiro-Wilk test [25] appears to be the most suitable for performing a normality test.

The data on daily cases of the COVID-19 showed nonnormal distribution, so the relationship between weather and COVID-19 incidence was studied using the Spearman rank correlation test.

\section{RESULTS AND DISCUSSION}

The city of Oran, the second largest city in Algeria, registered on March 19, 2020 its first case of COVID-19. 


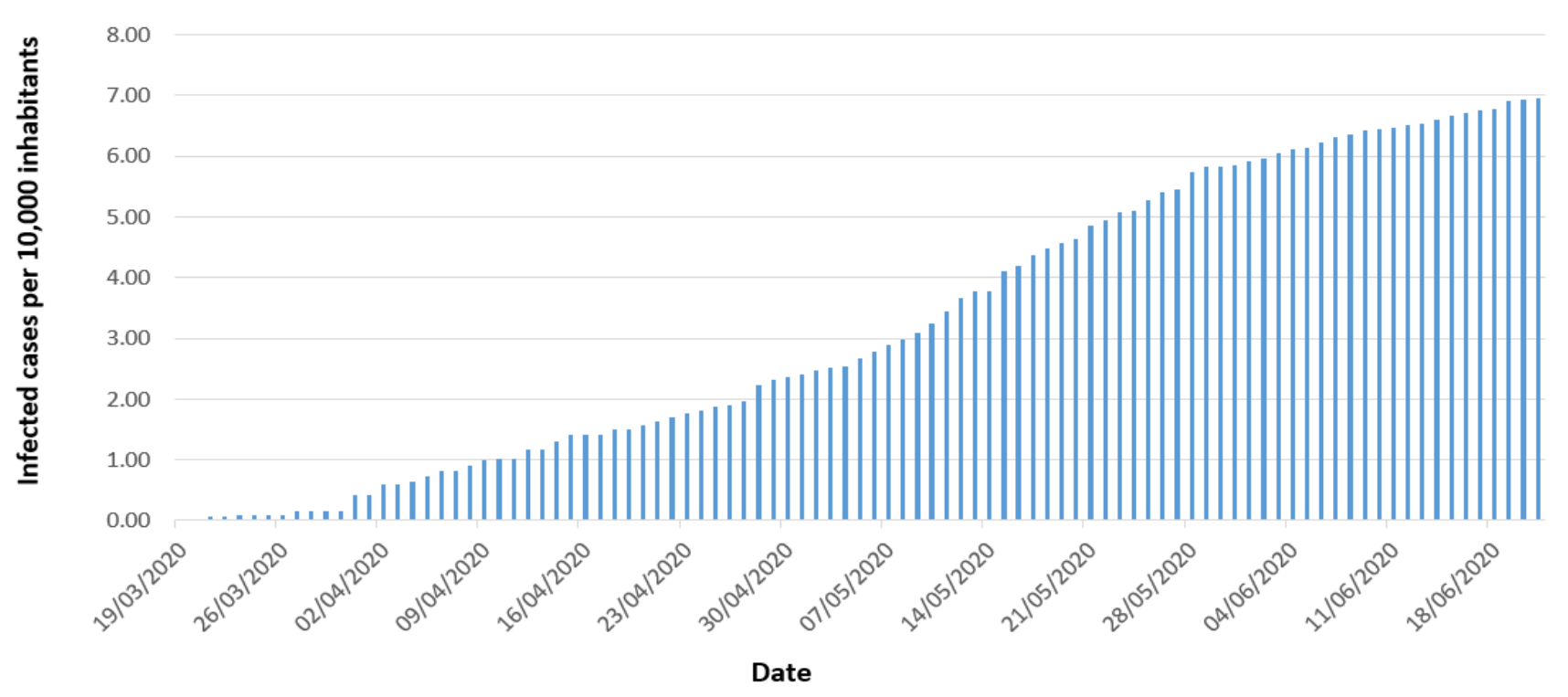

Figure 2. Number of infected cases per 10,000 inhabitants with Covid-19 in Oran since March 19, 2020 Source: [7]; compiled by authors

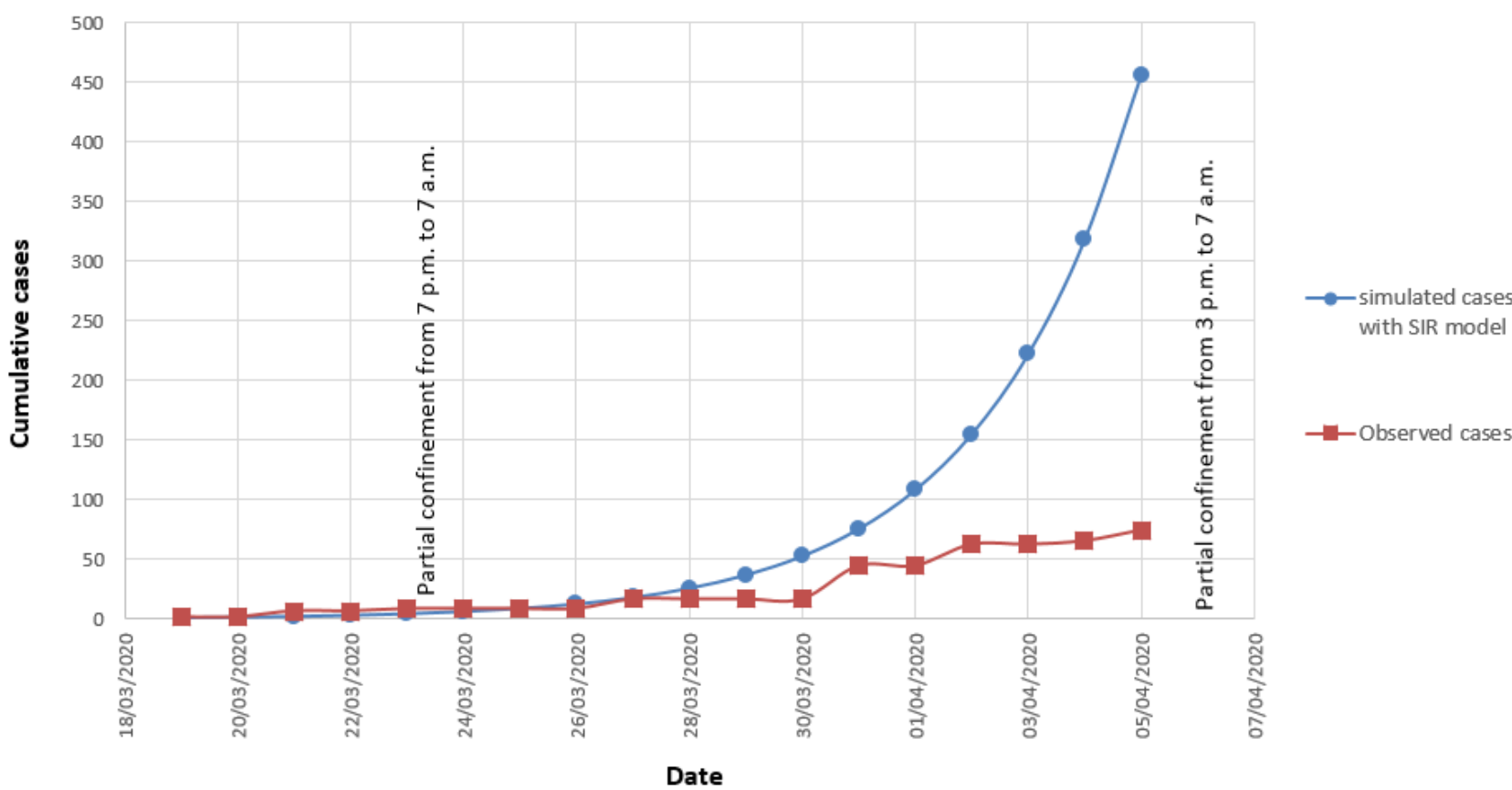

Figure 3. Comparison between simulated cases with SIR model and observed cases recorded by the MSPRH during the period from $19 / 03 / 2020$ to $05 / 04 / 2020$

Source: Authors

Figure 2 shows the progression of proven cases from COVID-19 to Oran since that date.

Several models can help monitor an outbreak and predict its evolution. The most classic being the SIR model [26] which is based on the work of the theory of Kermack et al. [27].

We carried out a simulation of the SIR model for the period from 03/19/2020, date when the first case was registered in Oran until 04/04/2020, date of application of the strictest partial containment in Oran.
The result of the simulation gives a basic reproduction number $\mathrm{R} 0=2.125638$ for the above-mentioned period. Thus, at the start of the outbreak, a person infected with COVID-19 could infect more than 2 people. This situation could have caused an exponential spread of the virus after 02 weeks as shown by the simulation of the SIR model presented in Figure 3. We can also see that this reproduction of the virus was probably slowed down by the sanitary and containment measures taken by Public powers. Indeed, containment is a barrier measure used to break the chains of virus transmission during an outbreak [28]. 


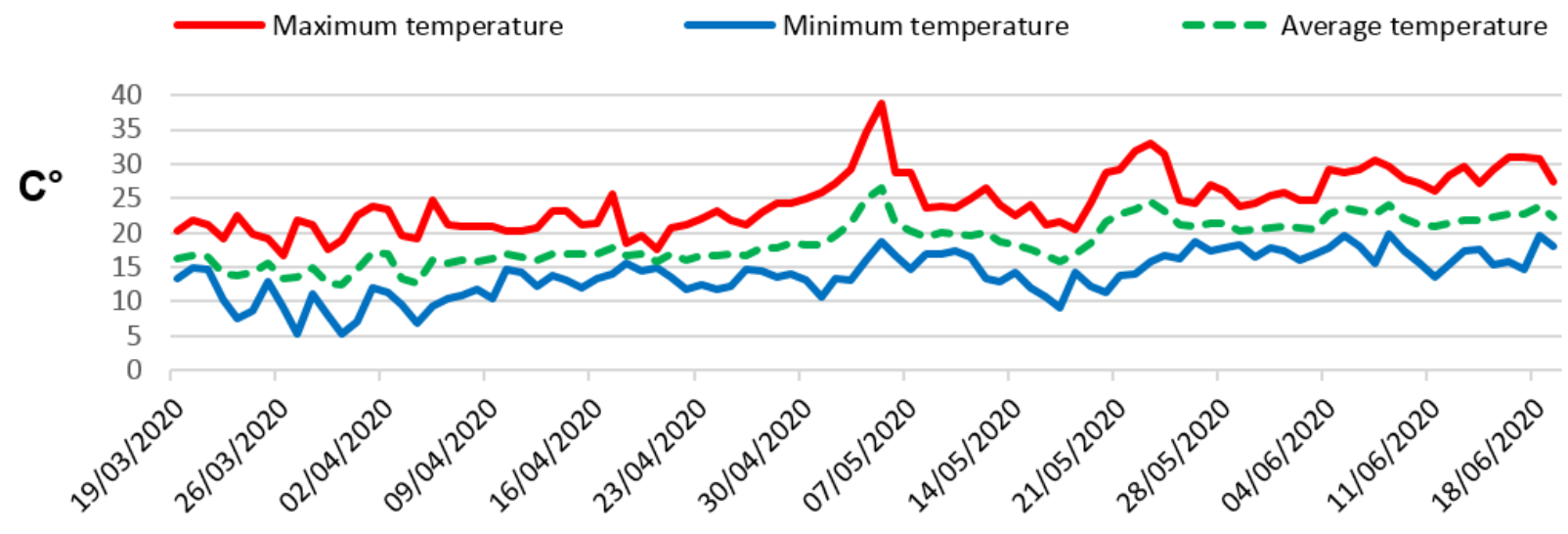

\section{Date}

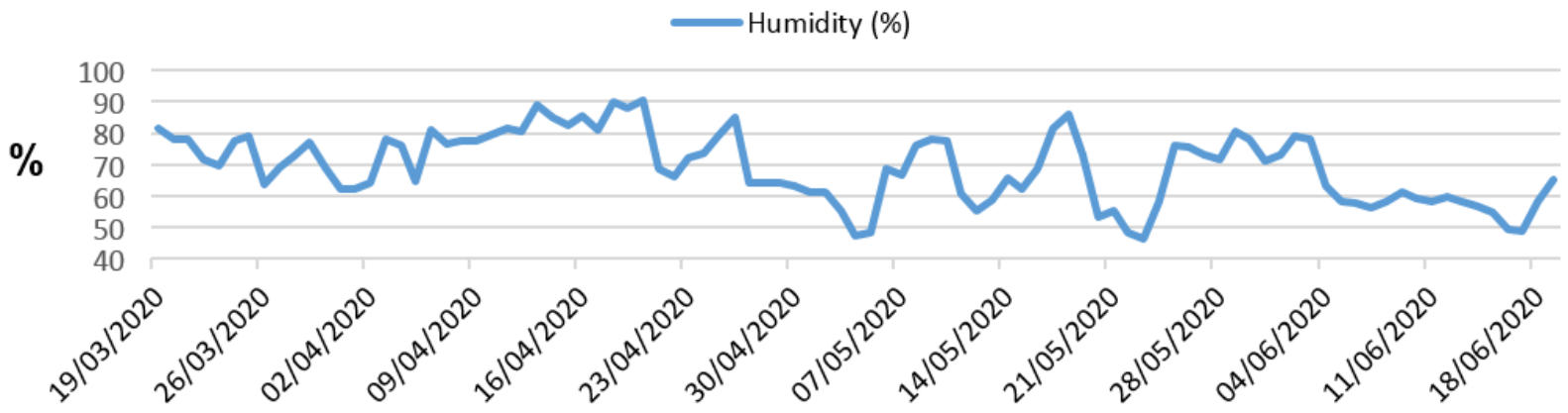

Date

Figure 4. Evolution of temperature and humidity during the studied period, at the city of Oran Source: authors
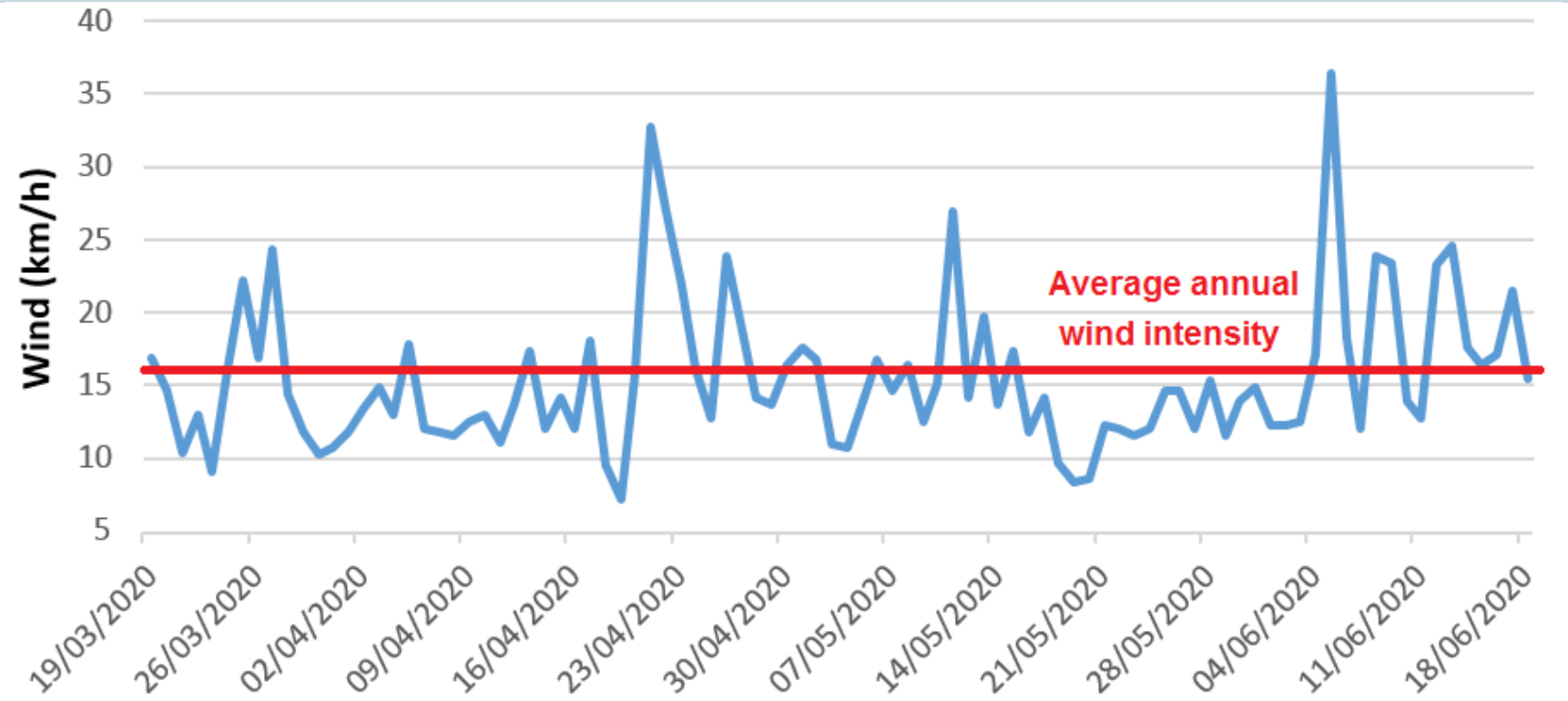

\section{Date}

Figure 5. Evolution of wind intensity during the studied period, at the city of Oran and the average annual wind intensity Source: authors

The evolution of temperature and humidity during the studied period is shown in Figure 4.

As shown in Figure 5, we collected wind data in $\mathrm{km} / \mathrm{h}$ from March to June, 2020. We also represented the average annual intensity of the wind in Oran, which according to Boudia et al. [29] is $15.12 \mathrm{~km} / \mathrm{h}$.

A Spearman rank correlation test was used to analyze this data. Table 1 shows the obtained coefficients. 
Table 1. Spearman correlation coefficients between infections of COVID-19 and weather variables

\begin{tabular}{cc}
\hline Weather variables & Spearman correlation coefficient \\
\hline Maximum temperature $\left({ }^{\circ} \mathrm{C}\right)$ & -0.1702 \\
\hline Minimum temperature $\left({ }^{\circ} \mathrm{C}\right)$ & -0.0937 \\
\hline Average temperature $\left({ }^{\circ} \mathrm{C}\right)$ & -0.168 \\
\hline Humidity $(\%)$ & 0.124 \\
\hline Wind $(\mathrm{km} / \mathrm{h})$ & -0.008 \\
\hline
\end{tabular}

Table 2. Spearman correlation coefficients between infections of COVID-19 and weather variables, taking into account the incubation period

\begin{tabular}{cc}
\hline Weather variables & Spearman correlation coefficient \\
\hline Maximum temperature $\left({ }^{\circ} \mathrm{C}\right)$ & 0.0129 \\
\hline Minimum temperature $\left({ }^{\circ} \mathrm{C}\right)$ & -0.312 \\
\hline Average temperature $\left({ }^{\circ} \mathrm{C}\right)$ & -0.108 \\
\hline Humidity $(\%)$ & -0.141 \\
\hline Wind $(\mathrm{km} / \mathrm{h})$ & 0.123 \\
\hline
\end{tabular}

The result does not show a significant correlation between the weather variables and the COVID-19 in Oran. However, taking into account the incubation period of COVID-19 has produced a significant result. Indeed, according to Wang et al. [30], the average incubation time of COVID-19 is approximately 6.4 days.

A 6-day shift in weather data from COVID-19 data found a significant correlation between new COVID-19 cases and minimum temperatures as shown in Table 2.

Spearman's correlation between minimum temperature and COVID-19 infections indicates a significant negative relationship. That is, when minimum temperatures decrease, COVID-19 infections increase.

During the studied period, the minimum temperatures varied between $5.3^{\circ} \mathrm{C}$ and $19.9^{\circ} \mathrm{C}$. The result confirms that temperature is an environmental driver of the Covid-19 outbreak as observed in China by Shi et al. [31].

\section{CONCLUSION}

Even if the COVID-19 pandemic in Oran seems relatively under control, the significant correlation between the minimum temperatures and the spread of the virus should alert health authorities to the risk of the epidemic worsening when the temperatures drop.

Given that meteorological parameters have a significant and consistent distribution of the seasonal behavior of respiratory viruses [32], it is desirable that the fight against COVID-19 be intensified during the summer in order to anticipate a possible upsurge contaminations that could appear in autumn and winter.

This work, which was limited to the study of the impact of meteorological parameters on the incidence of COVID-19 in the city of Oran, would benefit from being extended to other similar cities on the Mediterranean rim and to other parameters, like air pollution.

Indeed, the combination between air pollution and meteorological conditions with high relative humidity, low wind speed and fog, trigger a take-off of viral infectivity [33]. There has been a close correlation between regions with worse air pollution and diffusion of the virus [34].

Indeed, cities with atmospheric stability based on little wind and frequently high levels of air pollution had higher numbers of COVID-19 related infected individuals and deaths [35].

Furthermore, it is important to assess the environmental and social weaknesses of regions exposed to infectious diseases to prevent and / or contain new outbreaks of COVID-19 and other viral agents that generate a negative impact on public health and the economy of country [36].

There are many factors that may affect COVID-19 distribution and mortality in different areas [37]. In the presence of different viral diffusion mechanisms, it is also important to promote interdisciplinary research studies capable of analyzing the problem from different angles [38]. A comprehensive strategy to prevent future epidemics similar to COVID-19 has also to be designed in environmental and socioeconomic terms, that is in terms of sustainability science and environmental science, and not only in terms of biology, medicine, healthcare and health sector [39]. Globalization makes us share its benefits but also its damages which could become more and more recurrent.

Declaration of interest: The authors report no conflicts of interest.

Financial Disclosure: No financial support was received.

\section{REFERENCES}

1. Saadat S, Rawtani D, Hussain CM. Environmental perspective of COVID-19. Science of The Total Environment, 2020: $138870 . \quad$ doi: 10.1016/j.scitotenv.2020.138870.

2. Dalziel BD, Kissler S, Gog JR, Viboud C, Bjørnstad ON, Metcalf CJE, Grenfell BT. Urbanization and humidity shape the intensity of influenza epidemics in US cities. Science, 2018; 362(6410): 75-9. doi: 10.1126/science.aat6030.

3. Tosepu R, Gunawan J, Effendy DS, Lestari H, Bahar H, Asfian P. Correlation between weather and COVID-19 pandemic in Jakarta, Indonesia. Science of The Total Environment, 2020: $138436 . \quad$ doi: 10.1016/j.scitotenv.2020.138436.

4. Ma Y, Zhao Y, Liu J, He X, Wang B, Fu S, Luo B. Effects of temperature variation and humidity on the death of COVID-19 in Wuhan, China. Science of The Total Environment, 2020: $138226 . \quad$ doi: 10.1016/j.scitotenv.2020.138226. 
5. Qi H, Xiao S, Shi R, Ward M P, Chen Y, Tu W, Zhang Z. COVID-19 transmission in Mainland China is associated with temperature and humidity: A time-series analysis. Science of the Total Environment, 2020: 138778. doi: 10.1016/j.scitotenv.2020.138778.

6. Şahin M. Impact of weather on COVID-19 pandemic in Turkey. Science of The Total Environment, 2020: 138810. doi: 10.1016/j.scitotenv.2020.138810.

7. MSPRH. Ministère de la Santé, de la Population et de la Réforme Hospitalière, Algérie. 2020. Available at: http://COVID-19.sante.gov.dz/carte/

8. Moussaoui A, Auger P. Prediction of confinement effects on the number of covid-outbreak in Algeria. hal2020: 02547128v2. Available at: https://hal.archivesouvertes.fr/hal-02547128v2

9. Cohen J. Sick time. Science, 2020; 367: 1294-7. doi: 10.1126/science.367.6484.1294.

10. Ahmadi M, Sharifi A, Dorosti S, Ghoushchi SJ, Ghanbari $\mathrm{N}$. Investigation of effective climatology parameters on COVID-19 outbreak in Iran. Science of the Total Environment, 2020: $138705 . \quad$ doi: 10.1016/j.scitotenv.2020.138705.

11. Ma Y, Zhao Y, Liu J, He X, Wang B, Fu S, Luo B. Effects of temperature variation and humidity on the death of COVID-19 in Wuhan, China. Science of The Total Environment, 2020: $138226 . \quad$ doi: 10.1016/j.scitotenv.2020.138226.

12. Shephard RJ, Shek PN. Cold exposure and immune function. Canadian journal of physiology and pharmacology, 1998; 76(9): 828-36. doi: 10.1139/y98097.

13. Donaldson GC, Seemungal T, Jeffries DJ, Wedzicha JA. Effect of temperature on lung function and symptoms in chronic obstructive pulmonary disease. European respiratory journal, 1999; 13(4): 844-9. doi: 10.1034/j.1399-3003.1999.13d25.x.

14. Steel J, Palese P, Lowen AC. Transmission of a 2009 pandemic influenza virus shows a sensitivity to temperature and humidity similar to that of an $\mathrm{H} 3 \mathrm{~N} 2$ seasonal strain. Journal of virology, 2011; 85(3): 1400-2. doi: 10.1128/JVI.02186-10.

15. Li M, Zhou M, Yang J, Yin P, Wang B, Liu Q. Temperature, temperature extremes, and cause-specific respiratory mortality in China: a multi-city time series analysis. Air Quality, Atmosphere \& Health, 2019; 12(5): 539-48. doi: 10.1007/s11869-019-00670-3.

16. Davis RE, Dougherty E, McArthur C, Huang QS, Baker MG. Cold, dry air is associated with influenza and pneumonia mortality in Auckland, New Zealand. Influenza and other respiratory viruses, 2016; 10(4): 3103. doi: 10.1111/irv.12369.

17. Xie J, Zhu Y. Association between ambient temperature and COVID-19 infection in 122 cities from China. Science of the Total Environment, 2020; 724: 138201. doi: 10.1016/j.scitotenv.2020.138201.
18. Eslami $\mathrm{H}$, Jalili M. The role of environmental factors to transmission of SARS-CoV-2 (COVID-19). AMB Express, 2020; 10(1): 1-8. doi: 10.1186/s13568-02001028-0.

19. Moriyama M, Hugentobler WJ, Iwasaki A. Seasonality of respiratory viral infections. Annual review of virology, 2020: 7. doi: 10.1146/annurev-virology-012420-022445.

20. Solá DE, Wang L, Vázquez M, Méndez Lázaro PA. Weathering the pandemic: How the Caribbean Basin can use viral and environmental patterns to predict, prepare and respond to COVID-19. Journal of Medical Virology. 2020. doi: 10.1002/jmv.25864.

21. Bounoua L, Safia A, Masek J, Peters-Lidard C, Imhoff M L. Impact of urban growth on surface climate: A case study in Oran, Algeria. Journal of applied meteorology and climatology, 2009; 48(2): 217-31. doi: 10.1175/2008JAMC2044.1.

22. WMO (2020) World weather information service. Available at: https://worldweather.wmo.int

23. Bukhari Q, Jameel Y. Will coronavirus pandemic diminish by summer ?. Available at SSRN 3556998. 2020. doi: 10.2139/ssrn.3556998.

24. Rosario DK, Mutz YS, Bernardes PC, Conte-Junior CA. Relationship between COVID-19 and weather: Case study in a tropical country. International Journal of Hygiene and Environmental Health, 2020; 229: 113587. doi: 10.1016/j.ijheh.2020.113587.

25. Shapiro SS, Wilk MB. An analysis of variance test for normality (complete samples). Biometrika, 1965; 52(3/4): 591-611. doi: 10.2307/2333709.

26. Roques L, Klein E, Papaix J, Soubeyrand S. Modèle SIR mécanistico-statistique pour l'estimation du nombre d'infectés et du taux de mortalité par COVID-19. Rapport de recherche, INRAE. 2020.

27. Kermack WO, McKendrick AG. Contributions to the mathematical theory of epidemics. Proc R Soc A 1927; 115: 700-21. doi: 10.1098/rspa.1927.0118.

28. Badsi D, Terki K, Elkebir D, Benali D, Zitouni H, Mazour F, Mansouri M. Bulletin ${ }^{\circ} 1$ from 04-02 to 1804-2020 on the activities and the epidemiological situation of COVID-19 within the University Hospital of Oran-EHU. 2020.

29. Boudia SM, Guerri O. Investigation of wind power potential at Oran, northwest of Algeria. Energy Conversion and Management, 2015 105: 81-92. doi: 10.1016/j.enconman.2015.07.055.

30. Wang Y, Wang Y, Chen Y, Qin Q. Unique epidemiological and clinical features of the emerging 2019 novel coronavirus pneumonia (COVID-19) implicate special control measures. Journal of medical virology, 2020; 92(6): 568-76. doi: 10.1002/jmv.25748.

31. Shi P, Dong Y, Yan H, Zhao C, Li X, Liu W, Xi S. Impact of temperature on the dynamics of the COVID-19 outbreak in China. Science of The Total Environment, 2020: 138890. doi: 10.1016/j.scitotenv.2020.138890. 
32. Sajadi MM, Habibzadeh P, Vintzileos A, Shokouhi S, Miralles-Wilhelm F, Amoroso A. Temperature and latitude analysis to predict potential spread and seasonality for COVID-19. Available at SSRN 3550308. 2020. doi: 10.2139/ssrn.3550308.

33. Coccia M. Diffusion of COVID-19 Outbreaks: The Interaction between Air Pollution-to-Human and Human-to-Human Transmission Dynamics in Hinterland Regions with Cold Weather and Low Average Wind Speed. 2020a. doi: 10.2139/ssrn.3567841.

34. Sterpetti AV. Lessons learned during the COVID-19 virus pandemic. Journal of the American College of Surgeons, 2020; 230(6): 1092-3. doi: 10.1016/j.jamcollsurg.2020.03.018.

35. Coccia M. The effects of atmospheric stability with low wind speed and of air pollution on the accelerated transmission dynamics of COVID-19. International Journal of Environmental Studies, 2020b: 1-27. doi: 10.1080/00207233.2020.1802937.
36. Coccia M. An index to quantify environmental risk of exposure to future epidemics of the COVID-19 and similar viral agents: Theory and Practice. Environmental research, 2020c: $110155 . \quad$ doi: 10.1016/j.envres.2020.110155.

37. Sarmadi M, Marufi N, Moghaddam VK. Association of COVID-19 global distribution and environmental and demographic factors: An updated three-month study. Environmental Research, 2020; 188: 109748. doi: 10.1016/j.envres.2020.109748.

38. Bontempi E. Commercial exchanges instead of air pollution as possible origin of COVID-19 initial diffusion phase in Italy: more efforts are necessary to address interdisciplinary research. Environmental Research, 2020: $109775 . \quad$ doi: 10.1016/j.envres.2020.109775.

39. Coccia M. Factors determining the diffusion of COVID19 and suggested strategy to prevent future accelerated viral infectivity similar to COVID. Science of the Total Environment, 2020d: 138474 doi: 10.1016/j.scitotenv.2020.138474. 